\title{
When to Sow Your Seed for Optimal Forest Rehabilitation - Lessons from the Jarrah Forest of South Western Australia
}

\author{
T. Worthington Centre for Land Rehabilitation, The University of Western Australia, Australia
}

M.F. Braimbridge Centre for Land Rehabilitation, The University of Western Australia, Australia

S. Vlahos Worsley Alumina Pty Ltd, Australia

M. Tibbett Centre for Land Rehabilitation, The University of Western Australia, Australia

\section{$1 \quad$ INTRODUCTION}

As mining is a temporary land use (EPA, 1995), there is a need for the disturbed land to be rehabilitated in accordance with long term land use goals. In Australia, the objective of many post-mining rehabilitation programmes is to establish a native ecosystem similar to that of surrounding undisturbed sites (Bell, 2001). Successfully established native ecosystems have the advantage of being self-sustaining and resilient to disturbance, whilst supporting native fauna and requiring minimal long-term management inputs.

In Western Australia, the establishment of a native ecosystem following bauxite mining is typically achieved through topsoil return, broadcast seeding and planting of green stock as required (Roche et al., 1997; Vlahos et al., 1999). Direct seeding has been found to be the least costly way to establish native species and is necessary to supplement the seed bank stored in the returned topsoil (De Villiers et al., 2003; Koch and Ward, 1994; Turner, 2006; Ward et al., 1996). Typically, the composition of the applied seed mix reflects the desired species diversity of the mature rehabilitation and is based on estimated germination and establishment rates.

There is evidence to suggest that the floristic composition of rehabilitated bauxite mines in the south-west of Western Australia can reflect the initial vegetation complex, even many years after seeding (Grant and Loneragan, 2001; Koch and Ward, 1994; Norman et al., 2006). This, combined with the high cost of rehabilitation, makes it preferable to optimise the establishment of the desired plant community early in the rehabilitation process. However, ecosystem restoration is a complex process and there are many barriers to successful seedling emergence and establishment, including seed viability, ambient temperature, soil moisture, light, predation and competition effects (Beardsell and Richards, 1987; Majer et al., 1984; van der Valk and Pederson, 1989). Within the mining industry, the time of year that sowing occurs has been identified as a factor with the potential to impact on the abundance of emerged plants in newly established rehabilitation areas (Turner, 2006; Ward et al., 1996).

Where broadcast seeding is used to assist in the regeneration of plants on mined sites, sowing at an appropriate time can be a low cost way to maximise plant establishment (Brofas and Karetsos, 2002; Turner, 2006). In south-western Australia, germination usually occurs in late autumn and winter (Grant and Koch, 1997), and sowing in May has been found to result in greater seedling emergence than sowing in winter (July) (Turner, 2006).

In this paper, we present the findings of a research trial based at a bauxite mine in the south-west of Western Australia, which attempted to quantify the effect of different sowing times on seedling emergence and establishment. Seed was sown at three different times: mid dry season, late dry season and at the break of season. It was hypothesised that the early sowing would result in the poorest seedling emergence and establishment, as the seed would be exposed on the soil surface for many months before the break of season and consequently vulnerable to desiccation, predation and dispersal. 


\section{METHODOLOGY}

\section{$2.1 \quad$ Study Site}

The trial site was situated at the Worsley Alumina Pty Ltd (Worsley) Boddington Bauxite Mine (BBM), 130 $\mathrm{km}$ south east of Perth, Western Australia. The mine is located in the eastern low rainfall zone of the Jarrah (Eucalyptus marginata) forest and experiences a typical Mediterranean climate of hot dry summers and cool wet winters (Gentilli, 1989). The soils of the region, which are generally considered low in available phosphorous and nitrogen (Hingston et al., 1989), are described by McArthur (1991).

\subsection{Experimental Design}

The field trial was designed to assess the impact of time of sowing on seedling emergence and establishment. Seed from 18 jarrah forest species (Table 1) was sown in the mid dry season (24th January 2005), late dry season (4th April 2005) and at the break of season (23rd May 2005) (Figure 1). Seed was pre-treated according to Koch and Taylor (2000) and spread directly onto the soil surface in plots consisting of four parallel rows (30 cm apart, $3 \mathrm{~m}$ long). Plots were randomised within each of five experimental blocks. For each species, there was a desired establishment rate of 30 plants per plot. Estimated germination and establishment rates for the 18 species were obtained from Koch and Taylor (2000) and Worsley. These rates were used to calculate the total number of seeds required to give the desired 30 plants per plot (Table 1).

Direct return soil was spread on the trial area in January 2005 and scarified immediately prior to each sowing event. The trial was fenced to exclude herbivores and received a one-off application of super-phosphate fertiliser $(450 \mathrm{~kg} / \mathrm{ha})$ on 2nd September 2005.

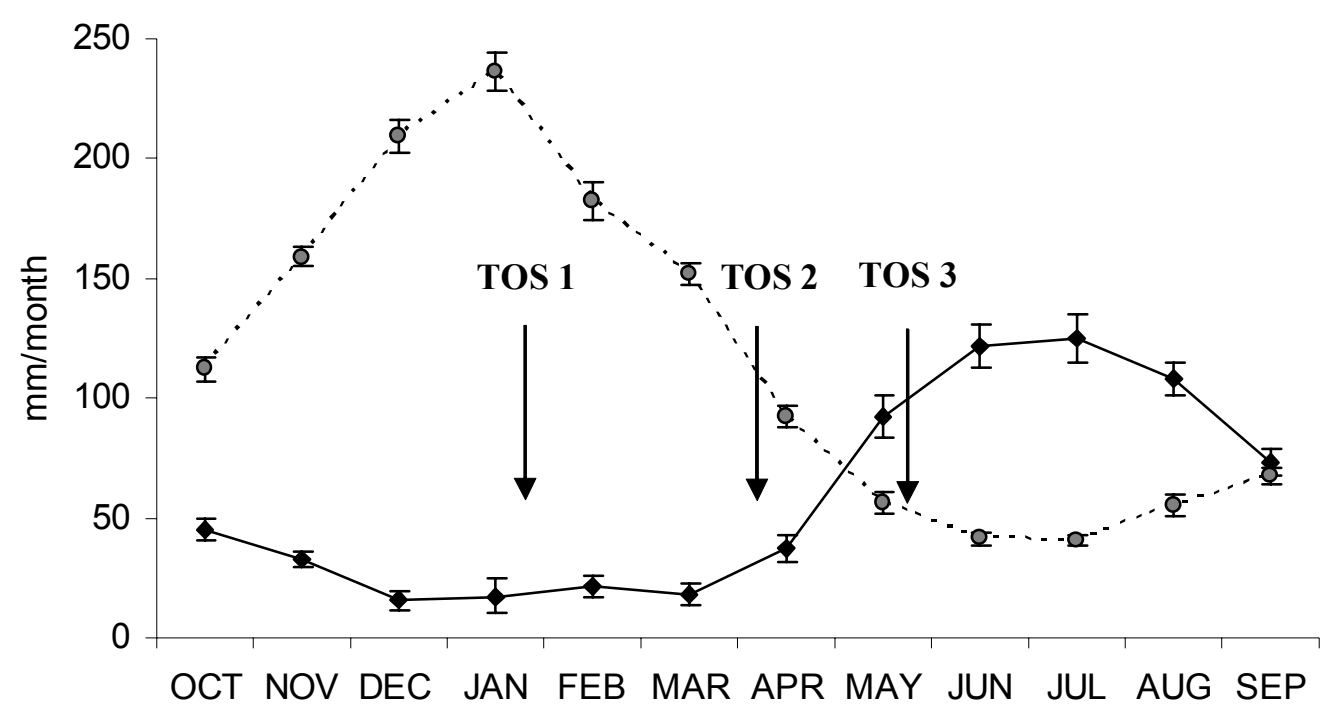

Figure 1 Average rainfall (-๑-) and pan evaporation (-o-) for the Boddington Bauxite Mine ( \pm S.E. of the mean). Values calculated on available monthly data from 1983 to 2006. Time of sowing (TOS) is indicated: TOS $1=$ mid dry season, TOS 2 = late dry season, TOS 3 = break of season. Data provided by Worsley Alumina Pty Ltd 
Table $1 \quad$ Number of seeds sown per plot for each of 18 Jarrah forest species

\begin{tabular}{|l|c|}
\hline \multicolumn{1}{|c|}{ Species } & Number of seeds sown per plot \\
\hline Acacia celastrifolia & 346 \\
\hline Acacia drummondii ssp drummondii & 256 \\
\hline Acacia urophylla & 220 \\
\hline Allocasuarina fraseriana & 323 \\
\hline Banksia grandis & 67 \\
\hline Bossiaea ornata & 502 \\
\hline Calothamnus quadrifidus & 560 \\
\hline Calothamnus sanguineus & 258 \\
\hline Corymbia calophylla & 143 \\
\hline Eucalyptus accedens & 2464 \\
\hline Eucalyptus marginata & 825 \\
\hline Eucalyptus wandoo & 765 \\
\hline Hakea undulata & 112 \\
\hline Kennedia prostrata & 278 \\
\hline Petrophile heterophylla & 1071 \\
\hline Phyllanthus calycinus & 2000 \\
\hline Trymalium ledifolium & 698 \\
\hline Xanthorrhoea preissii & 100 \\
\hline
\end{tabular}

\subsection{Monitoring and Assessment}

In late August 2005, seedling emergence was assessed. Emergence was considered to have occurred when cotyledons, leaves or phyllodes were evident above the soil surface. Total counts were made of the number of emerged seedlings within each species plot. Volunteer seedlings of other native or weedy species were ignored in these counts, but any volunteer seedlings of the species under assessment could not be distinguished. In order to assess establishment, seedlings were thinned to 5 plants per row (20 per plot) and individually marked. In April 2006, survivorship of the marked seedlings was assessed. Marked plants that had survived between August 2005 and April 2006 were considered to be established.

\subsection{Data Analysis}

Plant emergence counts were converted to percentages of the total number of seeds sown. All percentage data were arcsine transformed prior to analysis, with additional transformations performed as required to normalise the data. Establishment numbers were converted to percent survival of marked plants between August 2005 and April 2006. For comparison of emergence data within species following the three sowing treatments, one-way analyses of variance (ANOVA) were performed using SigmaStat version 3.5 (which included internal default tests for homogeneity of variances). Where a significant effect was detected by ANOVA, a Tukey post-hoc test was conducted. For seedling establishment data, descriptive statistics are shown (standard error of the mean). No probabilistic univariate analysis was performed due to the large range in starting sample size and complex distribution of subsequent data. 


\section{$3 \quad$ RESULTS}

\subsection{Effect of Time of Sowing on Seedling Emergence}

There was considerable variation in the emergence rates between species, ranging from a mean emergence of $45 \%$ for $A$. drummondii to $1 \%$ for $C$. calophylla (Figure 2). In addition to $A$. drummondii, comparatively high emergence was observed for $H$. undulata and T. ledifolium. All the large tree species (C. calophylla, E. accedens, E. marginata and E. wandoo) had low emergence, as did C. quadrifidus, K. prostrata and $P$. calycinus. Emergence of the remaining eight species ranged between approximately 8-15\% of total seed sown.

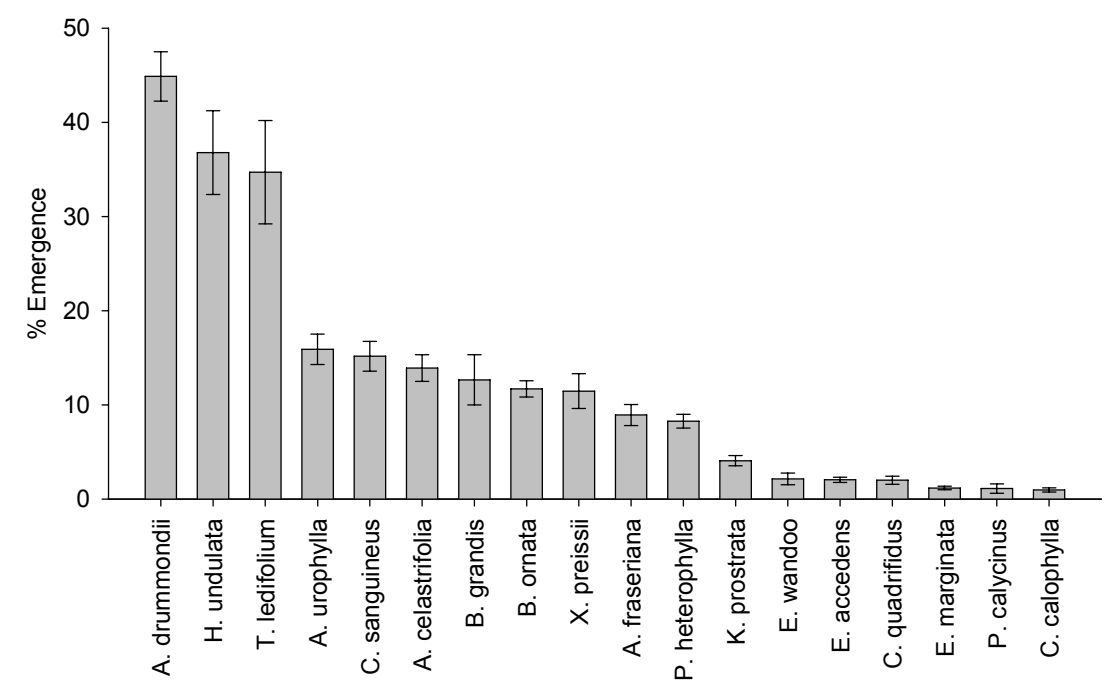

Figure 2 Emergence of 18 Jarrah forest species in August 2005 as percent of seeds sown. Values are means \pm S.E. $(n=15)$ of total emergence, disregarding time of sowing

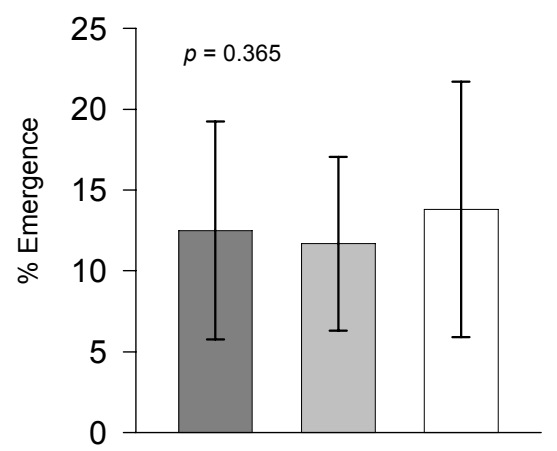

Figure 3 Total emergence of seedlings from all species following sowing in mid dry season $(\square)$, late dry season $(\square)$ and at the break of season $(\square)$. Values are means \pm S.E. $(n=5)$

Time of sowing was found to have no significant effect on the total number of seedlings emerged in August 2005 (Figure 3). However, five of the 18 species had significantly different emergence rates in response to time of sowing (Figure 5). Allocasuarina fraseriana had the highest seedling emergence in the mid (January) and late (April) dry season sowing treatments, whilst sowing at the break of season (May) resulted in poor emergence for this species. Eucalyptus marginata and P. heterophylla both had highest seedling emergence following sowing in the mid dry season and at the break of season. Eucalyptus wandoo and $H$. undulata performed best following sowing at the break of season. 
Of the other 13 species, seven had highest emergence following sowing late in the dry season. These were $A$. celastrifolia, A. urophylla, C. calophylla, C. sanguineus, E. accedens, K. prostrata and X. preissii (Figure 5). However, the difference in emergence following the three sowing times was extremely marginal for $E$. accedens and C. sanguineus. Sowing at the break of season led to the highest emergence of B. grandis, $C$. quadrifidus and T. ledifolium. In total, five species exhibited higher emergence following the mid season sowing than either the late or break of season sowings; these were A. drummondii, B. ornata, E. marginata, $P$. calycinus and $P$. heterophylla. Furthermore, the January sowing resulted in the second highest emergence rate for several species, including C. calophylla, H. undulata and X. preissii.

\subsection{Effect of Time of Sowing on Seedling Establishment}

The majority of species demonstrated $>70 \%$ seedling establishment between August 2005 and April 2006, irrespective of time of sowing. Some differences in establishment following the three sowing times were observed for the 18 species, however there was no single sowing treatment that resulted in consistently higher or lower establishment rates. Furthermore, high establishment was observed in many species that exhibited very low emergence rates. Sowing in the middle of the dry season (January) resulted in higher establishment of all of the Acacia species, as well as A. fraseriana, B. grandis, $H$. undulata and $P$. heterophylla seedlings. Eucalyptus accedens and $P$. calycinus had higher establishment from seed sown at the break of season. The end of season sowing (April) led to higher establishment of only two species, $C$. quadrifidus and E. marginata, but led to the lowest establishment rate for A. urophylla, B. grandis, E. accedens, H. undulata, T. ledifolium, and X. preissii. Banksia grandis, E. accedens, H. undulata, T. ledifolium and $X$. preissii exhibited similar establishment rates between the mid and break of season sowings. Bossiaea ornata, C. calophylla, C. sanguineus and K. prostrata all had establishment of almost $100 \%$, irrespective of sowing time.

\subsection{Site Climatic Conditions}

The trial site received no rainfall during January 2005, when the mid dry season sowing was conducted (Figure 4). February 2005 was also unseasonably dry, with the site receiving less than half the average monthly rainfall. April 2005, when the second sowing took place, was marginally wetter than usual but the site received more than double the monthly average rainfall at the break of season (May). July of that year was unseasonably dry and the site received less than half the monthly average rainfall. The emerged seedlings in the three sowing treatments were marked and thinned at the end of August 2005, an average rainfall month. Higher than average rainfall was recorded at the site in October 2005 and January 2006, but February, March and April of 2006 were all unseasonably dry months.

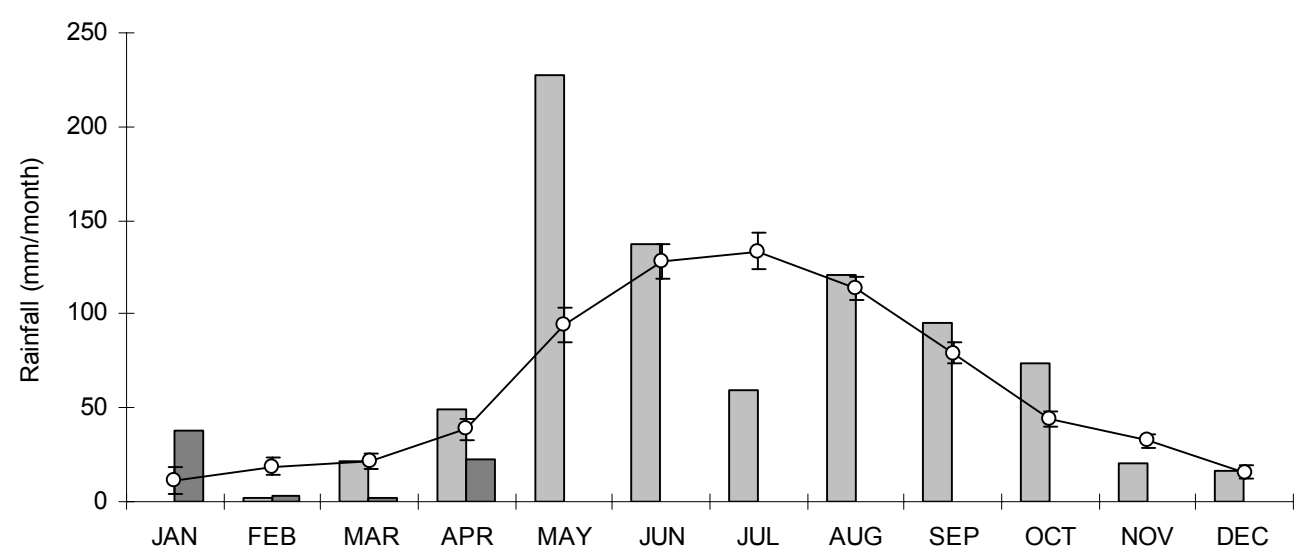

Figure $4 \quad$ Rainfall recorded at the Boddington Bauxite Mine in 2005 ( $\square$ ) and 2006 ( $\square$ ). Average rainfall per month (-O-) from 1983 to present is indicated (mean \pm SE). Data provided by Worsley Alumina Pty Ltd 

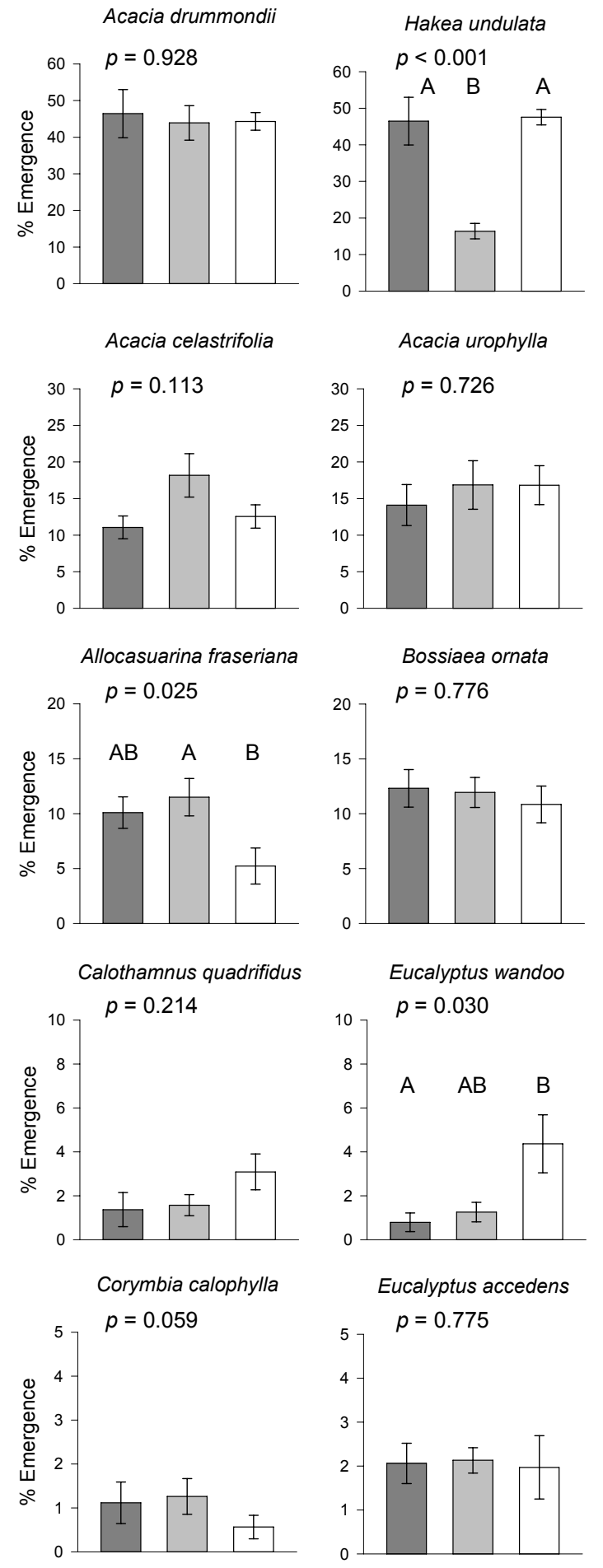
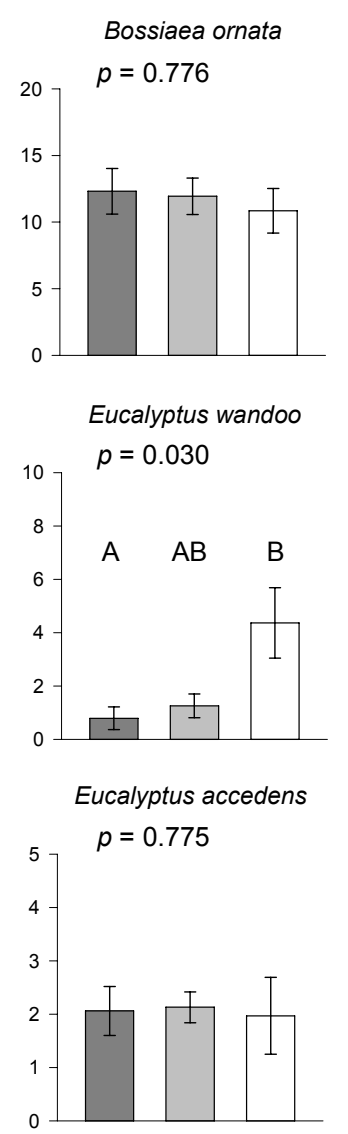
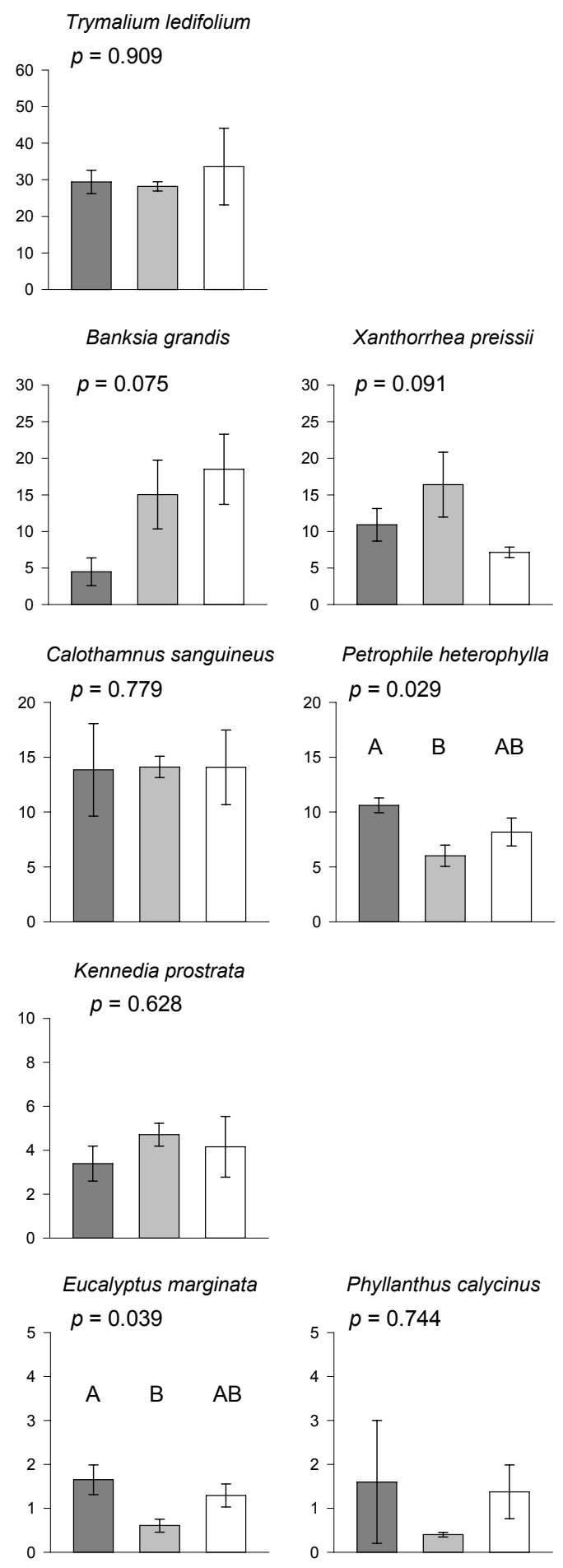

Figure 5 Percentage emergence of 18 Jarrah forest species following sowing in mid dry season $(\square)$, late dry season $(\square)$ and at the break of season $(\square)$. Values are means \pm S.E. $(n=5)$. Bars sharing the same letter are not significantly different at $p<0.05$ 

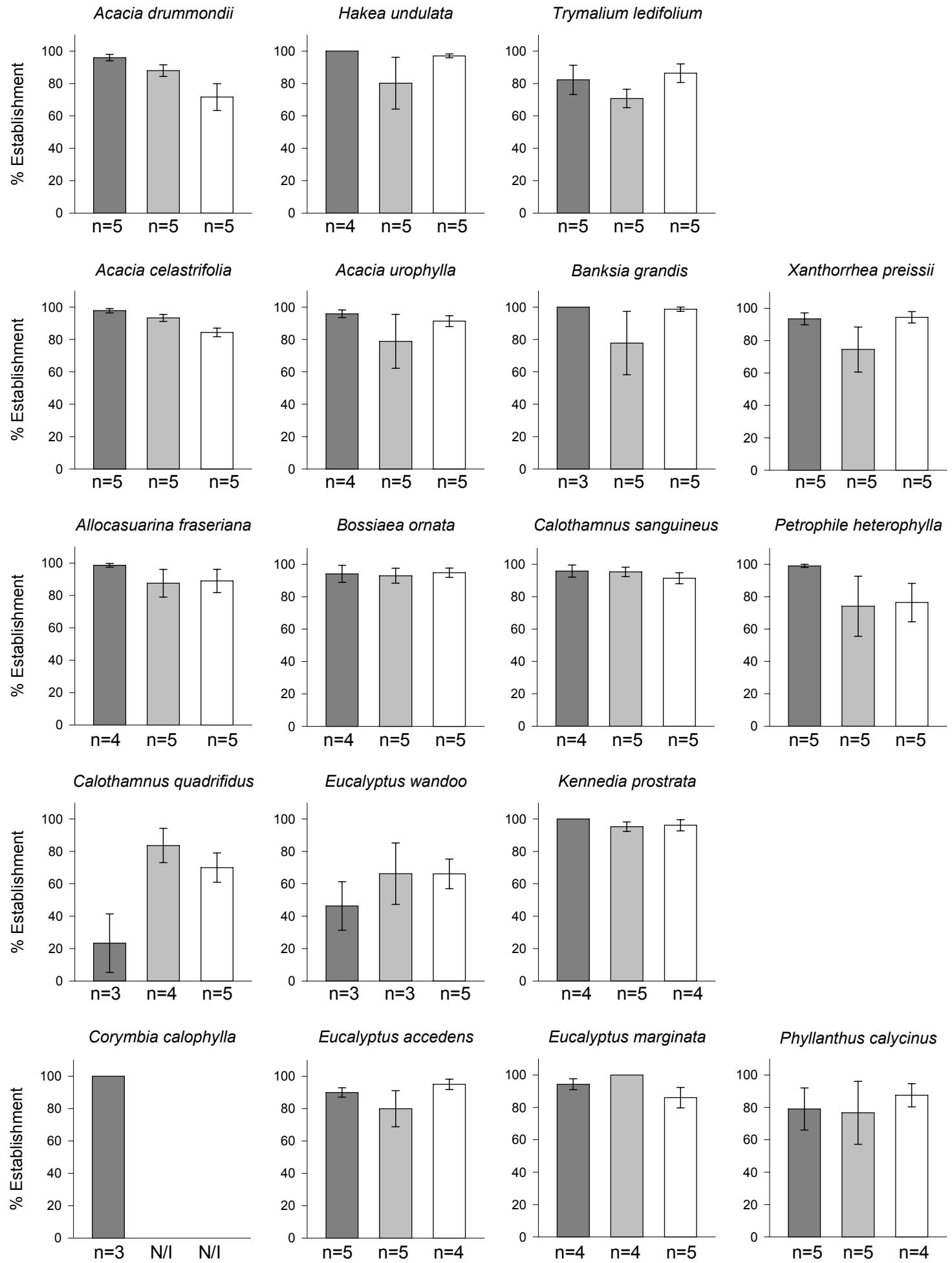

Figure 6

Percentage establishment of 18 Jarrah forest species following three sowing times: mid dry season ( $\square$ ), late dry season $(\square)$ and at the break of season $(\square)$. Values are means \pm S.E. and sample size $(n)$ is indicated. $N / I$ indicates the value was not included due to small sample size $(n<3)$ 


\section{DISCUSSION}

Time of sowing has the potential to significantly impact seedling emergence in rehabilitation areas. However, there is no single sowing time that will optimise the emergence of all species. Rather, some species benefit significantly from sowing in the middle of the dry season (January) whilst others demonstrate higher emergence following later sowing dates. Whilst it is not feasible for land managers to adjust sowing times on a species specific basis, understanding the effect of sowing schedule on field emergence rates may assist in the establishment of key species, as well as in the selection of appropriate seed mix compositions.

The emergence of the jarrah forest species by August 2005 appeared to be unrelated to the period since sowing. At the time of assessment, over 200 days had elapsed since the January sowing but only 94 since the sowing in late May. Despite the greater opportunity for germination and emergence following the early sowing, the latter had the highest number of plants. This suggests that sowing later in the year did not limit the opportunity for seedling emergence under the observed climatic conditions. However, only one assessment of emergence was completed and it is probable that there were seedling emergences and subsequent mortalities that were not observed, particularly in the early sowing treatment.

Seed fall from vegetation in the south-west of Australia occurs in late spring and early summer (Grant and Koch, 1997), with germination taking place during the following winter. Although the seed is exposed on the forest floor between these events, the canopy of the mature vegetation affords shade and protection from environmental extremes. In contrast, mine pits are bare of cover at the time of seeding. It was therefore expected that sowing several months prior to the break of season would provide increased opportunity for desiccation, dispersal and predation by insects such as ants, consequently reducing the amount of viable seed remaining in the experimental plots. However, this hypothesis proved unfounded and sowing in the middle of summer (January) resulted in higher total plant emergence than sowing towards the end of the dry season (April) (Figure 3). Prolonged storage of seed from Australian plant species at high temperature has been demonstrated to shorten after-ripening periods and increase germination rates (Mott, 1974; Mott, 1978). Therefore, it is possible that sowing earlier in the year may have exposed the seed to environmental conditions that broke dormancy and triggered germination at a rate high enough to negate any effects of increased predation or dispersal. If true, this would suggest that sowing in summer is a preferred option for mine site rehabilitation in this region.

Mature, non-dormant seeds will only germinate when specific environmental requirements, such as soil moisture or temperature, are met (Bell, 1999). Maximum seed germination and plant emergence are likely to occur when sowing is timed to coincide with these parameters. However, the cues required to trigger germination vary between species and are likely to reflect different ecological strategies. Those species that had highest emergence in the mid dry season sowing treatment, such as E. marginata and $P$. heterophylla, may secure a competitive advantage through germinating early in the season, but risk higher mortality in the event of sporadic rainfall.

For the majority of the 18 jarrah forest species, time of sowing had only a marginal effect on percent establishment. In excess of $70 \%$ of the seedlings of most species established, irrespective of sowing time. This indicates that germination and emergence are the critical phases in determining plant abundance in rehabilitation areas, as once a seedling has emerged the probability of it surviving and establishing is high. It should be noted, however, that the exclusion of herbivoures from the field site and the unseasonably high rainfall recorded in January 2006 may have resulted in a 'best case scenario' of seedling establishment. Nevertheless, as time of sowing resulted in considerably different emergence rates of the 18 species examined, it can be concluded that significantly different establishment rates are also likely to result. This has major implications for the long-term species diversity and community composition of rehabilitated area. In south-western Australia, rehabilitated mine sites have been found to follow the initial floristic composition model and the vegetation that emerges and establishes early will affect ecosystem function at the site for many years (Grant and Loneragan, 2001; Koch and Ward, 1994; Norman et al., 2006). For this reason, it is critical that the effects of sowing time on seedling emergence and establishment be understood if the mature rehabilitation is to successfully reflect the target community. 


\section{ACKNOWLEDGEMENTS}

The authors would like to acknowledge the funding and support provided by Worsley Alumina Pty Ltd to undertake this research. We would like to thank M. Ryan, H. Nielssen, R. Kaciuba, K. Bozanich and S. Davis for their contribution to the trial establishment and monitoring. We are also grateful to S. George, R. Beazley, B. Kennedy, E. O’Brien, B. Larkin and G. Custodio for their assistance.

\section{REFERENCES}

Beardsell, D. and Richards, D. (1987) Ecological aspects of seed germination. In: Langkamp (ed) Germination of Australian native plant seed. Inkata Press, Melbourne, pp. 14-19.

Bell, D.T. (1999) Turner Review No. 1 - The process of germination in Australian species, Australian Journal of Botany, 47, pp. 475-517.

Bell, L.C. (2001) Establishment of native ecosystems after mining - Australian experience across diverse biogeographic zones, Ecological Engineering, 17, pp. 179-186.

Brofas, G. and Karetsos, G. (2002) Revegetation of mining spoils by seeding of woody species on Ghiona Mountain, Central Greece, Land Degradation \& Development, 13, pp. 461-467.

De Villiers, A.J., Van Rooyen, M.W. and Theron, G.K. (2003) Similarity between the soil seed bank and the standing vegetation in the Strandveld Succulent Karoo, South Africa, Land Degradation \& Development, 14, pp. 527-540.

EPA (1995) Best Practice Environmental Management in Mining. In. Commonwealth of Australia, Canberra, Australia.

Gentilli, J. (1989) Climate of the Jarrah forest. In B.Dell, J.J. Havel and N. Malajczuk (eds) The Jarrah forest: a complex mediterranean ecosystem. Kluwer Academic Publishers, Dordrecht, Boston, pp. 23-40.

Grant, C.D. and Koch, J.M. (1997) Ecological aspects of soil seed-banks in relation to bauxite mining. Twelve year old rehabilitated mines, Australian Journal of Ecology, 22, pp. 177-184.

Grant, C.D. and Loneragan, W.A. (2001) The effects of burning on the understorey composition of rehabilitated bauxite mines in Western Australia: community changes and vegetation succession, Forest Ecology and Management, 145 , pp. 255-279.

Hingston, F.J., O'Connell, A.M. and Grove, T.S. (1989) Nutrient cycling in the Jarrah forest. In: The Jarrah forest: a complex mediterranean ecosystem. Kluwer Academic Publishers, Dordrecht, Boston, pp. 155-177.

Koch, J.M. and Taylor, S.K. (2000) Seed germination records from Alcoa's Marrinup Nursery. Alcoa World Alumina Australia, Perth, W.A.

Koch, J.M. and Ward, S.C. (1994) Establishment of understorey vegetation for rehabilitation of bauxite-mined areas in the Jarrah forest of Western-Australia, Journal of Environmental Management, 41, pp. 1-15.

Majer, J.D., Day, J.E., Kabay, E.D. and Perriman, W.S. (1984) Recolonization by ants in bauxite mines rehabilitated by a number of different methods, Journal of Applied Ecology, 21, pp. 355-375.

McArthur, W.M. (1991) Reference soils of south-western Australia. Western Australia. Dept. of Agriculture, Perth, W.A.

Mott, J.J. (1974) Mechanisms controlling dormancy in arid zone grass Aristida-Contorta.1. Physiology and mechanisms of dormancy, Australian Journal of Botany, 22, pp. 635-645.

Mott, J.J. (1978) Dormancy and germination in 5 native grass species from savannah woodland communities of Northern Territory, Australian Journal of Botany, 26, pp. 621-631.

Norman, M.A., Koch, J.M., Grant, C.D., Morald, T.K. and Ward, S.C. (2006) Vegetation succession after bauxite mining in western Australia, Restoration Ecology, 14, pp. 278-288.

Roche, S., Koch, J.M. and Dixon, K.W. (1997) Smoke enhanced seed germination for mine rehabilitation in the southwest of Western Australia, Restoration Ecology, 5, pp. 191-203.

Turner, S.R. (2006) Influence of polymer seed coatings, soil raking, and time of sowing on seedling performance in post-mining restoration, Restoration ecology, 14, pp. 267-277.

van der Valk, A.G. and Pederson, R.L. (1989) Seed banks and the management and restoration of natural vegetation. In: Leck, Parkerand Simpson (eds) Ecology of soil seed banks. Academic Press, San Diego. 
Vlahos, S., Bastow, B.B. and Rayner, G.A. (1999) Bauxite mining rehabilitation in the northern Jarrah forest. In: Fifth International Alumina Quality Workshop, vol. 2, Bunbury, Western Australia, pp. 559-569.

Ward, S.C., Koch, J.M. and Ainsworth, G.L. (1996) The effect of timing of rehabilitation procedures on the establishment of a jarrah forest after bauxite mining, Restoration Ecology, 4, pp. 19-24. 